\title{
TWELVE YEARS OF DAILY WEATHER DESCRIPTIONS IN NORTH AMERICA IN THE EIGHTEENTH CENTURY (MEXICO CITY, I775-86)
}

\author{
F. Domínguez-Castro, M. C. Gallego, J. M. Vaquero, R. García Herrera, \\ M. Peña-Gallardo, A. El Kenawy, and S. M. Vicente-Serrano
}

\begin{abstract}
Zúñiga's weather diary provides a unique record of meteorological descriptions in Mexico City from 1775 to 1786, including the 1785/86 "hunger year" (strong drought and frosts), which has no analog in the instrumental period.
\end{abstract}

U nderstanding the preinstrumental climate variability requires, among other things, that scientists have access to data from both climate

AfFiliations: Domínguez-Castro, Peña-Gallardo, and VicenteSerrano-Instituto Pirenaico de Ecología, Consejo Superior de Investigaciones, Zaragoza, Spain; Gallego AND VAQUERODepartamento de Física, Universidad de Extremadura, Badajoz, Spain; García Herrera-Departamento de Física de la Tierra y Astrofísica, Universidad Complutense de Madrid, Madrid, Spain and Instituto de Geociencias (IGEO, CSIC-UCM), Madrid, Spain; El KenaWy-Instituto Pirenaico de Ecología, Consejo Superior de Investigaciones, Zaragoza, Spain, and Department of Geography, Mansoura University, Mansoura, Egypt

CORRESPONDING AUTHOR: F. Domínguez-Castro, f.dominguez.castro@gmail.com

The abstract for this article can be found in this issue, following the table of contents.

DOI:10.II75/BAMS-D-I8-0236.I

A supplement to this article is available online (I0.II75/BAMS-D-18-0236.2).

In final form 20 March 2019

(C2019 American Meteorological Society

For information regarding reuse of this content and general copyright

information, consult the AMS Copyright Policy. proxies and instrumental meteorological series during a certain period of overlapping data. This period is usually short (50-100 years), given the general lack of instrumental series longer than 100 years (e.g., Camuffo and Jones 2002; Zaiki et al. 2006; Brázdil et al. 2012; Domínguez-Castro et al. 2014; Murphy et al. 2018) in most parts of the world outside Europe. Moreover, the anthropogenic emission of greenhouse gases in the postindustrial period may affect the climate within this short period, making it difficult to isolate the natural variability signal and separate it from the anthropogenic component. Thus, the transfer functions that relate proxies and meteorological series are subject to different levels of uncertainty. In Latin America, the available instrumental period is shorter than in most other regions of the globe, with climate proxies being generally far from the locations of the longest instrumental series (Villalba et al. 2009). However, although some initiatives of meteorological data rescue-for example, Latin American Climate Assessment \& Dataset (LACA\&D) (Van Den Besselaar et al. 2015), Atmospheric Circulation Reconstructions over the Earth (ACRE) (Allan et al. 2011), and Early Meteorological Records from Latin 
America and Caribbean (EMERLAC) (DomínguezCastro et al. 2017a) - have been initiated in the region, much effort is still desired in this avenue, requiring further human and financial resources.

The use of documentary sources allows us, on certain occasions, to overcome these problems by providing high-resolution and continuous information. This is the case of weather diaries, which provide firsthand information in a sequential and continuous way that may reach subdaily resolution. The time coverage of the weather diaries usually ranges from months to a lifetime. Most of the weather diaries are located either in Europe (e.g., Pfister et al. 1999; Brázdil and Kotyza 1996; Raicich 2008; Brázdil et al. 2008; Domínguez-Castro et al. 2015; Sanderson 2018; Metzger and Tabeaud 2017) or the United States (e.g., Fiebrich 2009; Mock et al. 2007; Bernhardt 2015) and to a lesser extent in other regions of the globe (e.g., Maejima 1966; Mikami 1993). Special cases of weather diaries are the ships' logbooks that provide information about the meteorological conditions in the oceans [see Wheeler and García-Herrera (2008) or García-Herrera et al. (2018) for a review].

In Mexico, preinstrumental climate has been studied through natural proxies, such as lake records (e.g., Butzer and Butzer 1993; Hodell et al. 2012), corals (e.g., VásquezBedoya et al. 2012), speleothems (e.g., Brenner et al. 2003; Medina-Elizalde and Rohling 2012), and tree rings (e.g., Stahle et al. 2016; Acosta-Hernández et al. 2017). Documentary sources used to date are mostly of agricultural, religious, or governmental origins (Florescano 1976, 1986; Swan 1981; Endfield and O'Hara 1997; Endfield 2007; Garza-Merodio 2002, 2014; Merodio 2007; Mendoza et al. 2005, 2007). However, while they are good at the identification of extreme events with severe societal impacts, such as droughts or floods (e.g., DomínguezCastro et al. 2010, 2018), they usually provide information at coarser resolution than daily.

In this paper, we analyze

the records of a weather

\footnotetext{
FIG. I. Location map. (top) Current Mexico aerial photo; (bottom) Manuel Villavicencio's map of Mexico City ( 12 Dec 1782) (roughly the orange area in the top panel).
} 
diary registered in Mexico City during the period 1775-86. To our knowledge, this is the earliest observational data collection with daily resolution rescued in the region.

THE OBSERVER. The observer was Felipe de Zúñiga y Ontiveros (FZO) (Oaxtepec, 1717-Mexico City, 1793). He signed his works as Philomathematician of the court and surveyor of lands, waters and mines of the kingdom appointed by His majesty. He had a printing house where, at least, 782 titles were published. The main topics of these books were religion (587), politics (60), almanacs and calendars (48), and science (34). The scientists more

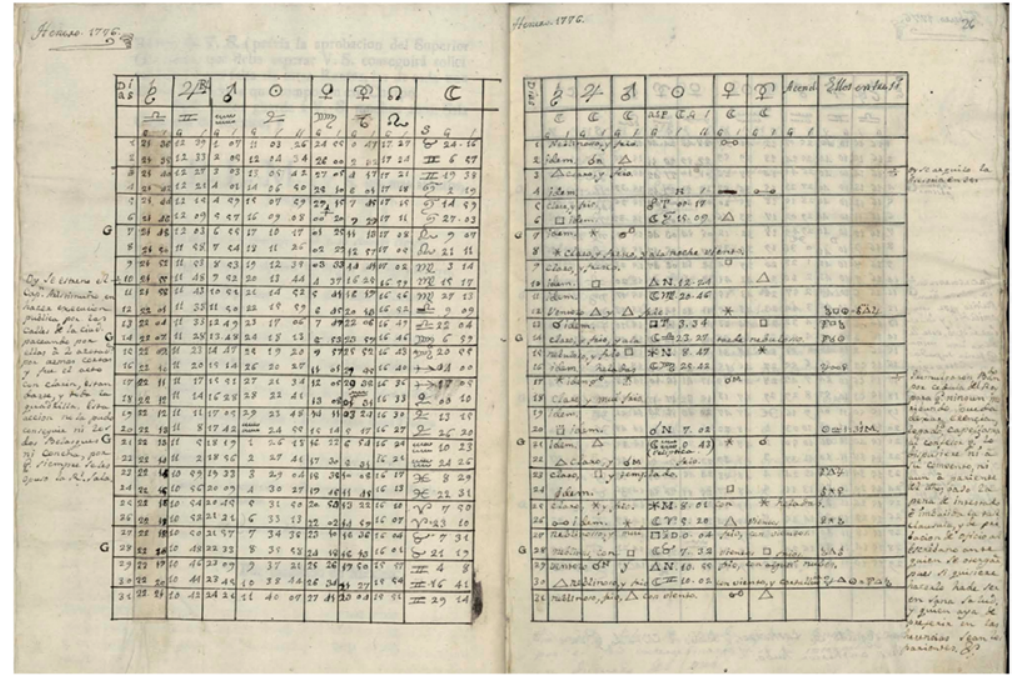

Fig. 2. Page of the manuscript Ephemérides astronómicas calculadas al meridiano de México, años 1775-86 from Jan 1776 (courtesy of the National Library of Spain). frequently published by FZO were

Antonio de León y Gamma, José Antonio Alzate, and José Ignacio Bartolache, who are important figures of the history of science in America. For a detailed biography of FZO, the work of Suárez Rivera (2005) can be consulted. FZO lived at Jesus Street in Mexico City until 22 July 1781, when he moved to Espíritu Santo Street. The printing house (Nueva Antuerpiana) was located from 1761 at La Palma Street, but it was also moved to Espíritu Santo Street in 1781. All these places are located in the current historic downtown district of Mexico City. As such, we can assume that the weather observations were made in the actual city center (approximate coordinates $19.43^{\circ} \mathrm{N}, 99.14^{\circ} \mathrm{W}$ ) (Fig. 1).

FZO was a self-taught scientist, author of the Efemérides Calculadas y Pronosticadas Según el Meridiano de México (Ephemerides Computed and Predicted According to the Meridian of Mexico) published from 1752 to 1793 . He also was the publisher of the Ephemerides since 1762. This publication was an almanac with information about holidays, the position of celestial bodies during the year, and recommendations for farmers. These kinds of almanacs were common in many European countries at the time (Eisinger 1954; Lisboa 1989). His work with the almanacs was recognized by José Antonio Alzate. On 4 January 1773, he wrote in the Gacetas Literarias (Literary Gazettes), "The advice given by Felipe Ontiveros (in the almanac of this year) to the farmers, to sow the corn called tresmesino, when frosts kill those regularly sown, is an excellent advice, which will prevent the shortage of supplies" (Alzate 1831, p. 164) (see quotation 1 in the online supplemental material for the original Spanish; https://doi.org//0.II75/BAMS -D-18-0236.2).

THE DIARY. The weather descriptions analyzed here have been retrieved from the manuscript "Ephemérides astronómicas calculadas al meridiano de México, años 1775-1786" written by FZO. The manuscript is preserved in the National Library of Spain (signature MSS/13244), and a digital copy is available online (http://bdh-rd.bne.es/viewer .$v m$ ? id $=0000$ I 29888\&page=I). The manuscript has 272 pages and seems to be a draft of the yearly published Efemérides Calculadas y Pronosticadas Según el Meridiano de México during the period 1775-86. The manuscript contains all the information published in the Efemerides (celebration dates, astronomical ephemerides, etc.) and a weather diary (Fig. 2). It also has plenty of margin notes that cover a wide range of topics: for example, personal notes, rogation ceremonies, public announcements, the appearance of comets, and the occurrence of earthquakes. Moreover, the manuscript also contains printed pages of public announcements or handwritten pages with notes and mathematical calculations. Recently, DomínguezCastro et al. (2017b) have retrieved and analyzed two sunspot sketches (9 January and 29 December 1777) that appear among these notes.

The weather information is continuous during 12 years (1 January 1775-31 December 1786) and provides information about precipitation, temperature, wind, frost, hail, fog, thunderstorms, and extreme phenomena (hurricanes, snowfall, etc.). The descriptions are generally short and concise (e.g., "clouds and 
rainfalls" on 14 July 1776), but they can also be longer when the atmospheric conditions changed during the day (e.g., "cloudy, in the evening wind, thunders and long rainfalls. Snow in the hills" on 22 March 1776). Unfortunately, there are no instrumental data in the diary.

We transcribed all the daily meteorological observations handwritten by FZO. The transcriptions are available upon request to the authors. Then we indexed all the meteorological variables according to the following criteria:

- Precipitation: We computed the frequency of rainy days. We defined a rainy day as a day for which the description includes rain, regardless of its intensity. The most frequent Spanish words to describe rain in the manuscripts are aguacero (showers) and lluvia (rain).

- Temperature: We applied content analysis (Baron 1982; Prieto et al. 2005) to the temperature adjectives used by FZO. After a preliminary analysis and taking into account the temperature descriptors, we built a temperature index of five categories (1-5): very cold, cold, temperate, hot, and very hot. When the weather description for a particular day had no information about temperature, we kept the category of the last day with information. The temperature has low variability at daily scale, so it is possible that FZO should have tried to save time recording only important changes in temperature. Nevertheless, it is difficult to confirm this hypothesis. So the interpretation of this variable should be done with care.

- Frost, hail, fog, thunderstorm, and wind: We generated daily binary series (presence or absence) for each meteorological phenomenon. Intensity or subdaily duration of the event was not taken into account. The most common Spanish words for each event are helada (frost), granizo (hail), neblinoso (foggy), relámpagos y truenos (thunderstorm), and viento (wind).

Some biases associated to noninstrumental weather descriptions are difficult to correct, which must be considered as a limitation. They have been reviewed in Brázdil et al. (2010). Some of the limitations that can affect the FZO diary are as follows:

The observer described the weather based on his own perception, which was influenced by the climate of his lifetime. This bias mainly affects the perception of the "normal" weather, and it is critical when comparing records from different observers. In this study, FZO was the only observer during the whole period, which should limit the bias. Moreover, this only applies to temperature. The rest of the variables in the diary are analyzed only by their presence or absence (rainfall, frost, hail, fog, thunderstorm, and wind), which leaves little room for interpretation or ambiguity.

Seasonal biases due to the tendency to record events only during particularly relevant seasons (e.g., sowing and harvesting periods). Even more, since the weather observations were associated to the astronomical activity, it is highly unlikely that this bias could be relevant. This is reinforced by our comparison with the current climate that does not show an important seasonal bias (see next section).

Changes in the location of observations or landuse changes can produce a nonclimatic signal in the record. The best way to minimize these biases is to have the best possible metadata about the observer, socioeconomic context, and agricultural changes during the time of observation. Fortunately, proper information about these aspects is provided by FZO as margin notes in the diary.

\section{CLIMATE IN MEXICO CITY (I775-86) COM- PARED WITH MODERN INSTRUMENTAL \\ DATA. Since there is no instrumental series over-} lapping with FZO's writings, we used the longest instrumental series available from Mexico City just as a reference to compare the climatologies obtained from FZO. The longest series are from Tacubaya Central Observatory. The measurements started at the Castillo de Chapultepec $\left(19^{\circ} 25^{\prime} \mathrm{N}, 99^{\circ} 11^{\prime} \mathrm{W}\right.$; 2,325 m MSL) on 6 March 1877. In 1883, the station was relocated to Tacubaya, where it was first located in the archbishop's palace. Later on, in 1908, it was moved to the observatory (contiguous buildings) $\left(19^{\circ} 24^{\prime} \mathrm{N}, 99^{\circ} 12^{\prime} \mathrm{W} ; 2,309 \mathrm{~m} \mathrm{MSL}\right)$, where it continued until today (Fig. 1).

The precipitation series is nearly complete with only 135 missing days $(0.26 \%)$ during the period 1877-2016. These gaps have been filled with the closest meteorological station, Colonia Americana $\left(19^{\circ} 25^{\prime} \mathrm{N}, 99^{\circ} 12^{\prime} \mathrm{W} ; 2,271 \mathrm{~m} \mathrm{MSL}\right.$ ) (Fig. 1). As a result, a series of rainy days were created considering all days with precipitation above $0 \mathrm{~mm}$.

The maximum and minimum temperature series at Tacubaya cover the same period as precipitation but with more gaps (3.5\%). Moreover, the expansion of the megacity and the extreme land-use changes have induced an important heat island effect in the last years (Jauregui 1997). For these reasons, we have employed only the first 30 complete years for comparison with the FZO temperature index, that is, from 1878 to 1908 
(1895 has no data). A series of daily mean temperature was simply computed as $(\operatorname{Tmax}+\operatorname{Tmin}) / 2$.

A basic quality control based on a tolerance test, analysis of temporal consistency, and internal coherence (Domínguez-Castro et al. 2017a) classified the $1.3 \%$ of the maximum temperature and the $0.8 \%$ of the minimum temperature data as suspicions values. The precipitation does not show suspicious data. All the suspicious data were deleted.

Monthly totals of days with hail, fog, and thunderstorms are available during the period 1981-2016. The series show some gaps (2.9\%). However, it was not possible to fill these gaps, because of lack of close stations with similar distribution of these events.

Different approaches have been applied to study the annual cycle and the annual variability for each variable, taking into account the available period and the frequency of each variable.

Rainy days. To compare the FZO climatology of rainy days (monthly means of 12 years) and the rainfall climatology at Tacubaya, we generated fifty $12-\mathrm{yr}$ random time series of rainy days from the original Tacubaya series by using a random sampling method (Matsumoto and Nishimura 1998). Figure 3a shows the monthly climatology of the rainy days $(>0 \mathrm{~mm})$ during the FZO period (1775-86) (red line) and the 50 randomly created climatologies from the Tacubaya period (1877-2016) (gray line). The distributions are very similar. They show a wet season from May to
October with a peak in July (around 22 days in FZO) and a dry season from November to December, with an average monthly mean generally lower than 5 days. The variability of Tacubaya data seem to concur well with that of FZO data, given that its sampled distributions are within the FZO mean plus and minus one standard deviation (SD) range provided by FZO. Overall, FZO shows higher variability ( $\mathrm{SD}=27$ days) than Tacubaya (SDs ranging between 7.9 and 25.4 days) and slightly higher values during the peak of the rainy season (June-August).

We also computed the monthly, seasonal, and annual frequencies for all series. Here, we considered two extended seasons: i) the wet season from May to October (MJJASO) and ii) the dry season from November to April (NDJFMA). To study the interannual, interseasonal, and intermonthly variability, we computed anomalies in the frequency of rainy days at annual, seasonal, and monthly resolution, taking 1775-86 and 1877-2016 as reference periods for FZO and Tacubaya, respectively. The monthly and seasonal rainy day anomalies during the FZO period have a range of variability similar to those of the Tacubaya series. The most anomalous wet season during FZO was in 1786, with an anomaly of -30 days; similar anomalous wet seasons were recorded at Tacubaya in 1905 and 1909 (-31 days) (Figs. 4a,b). At the monthly scale, few months with a positive anomaly appear during the dry periods of $1780 / 81$ and $1785 / 86$. On the other hand, wet conditions prevailed during the
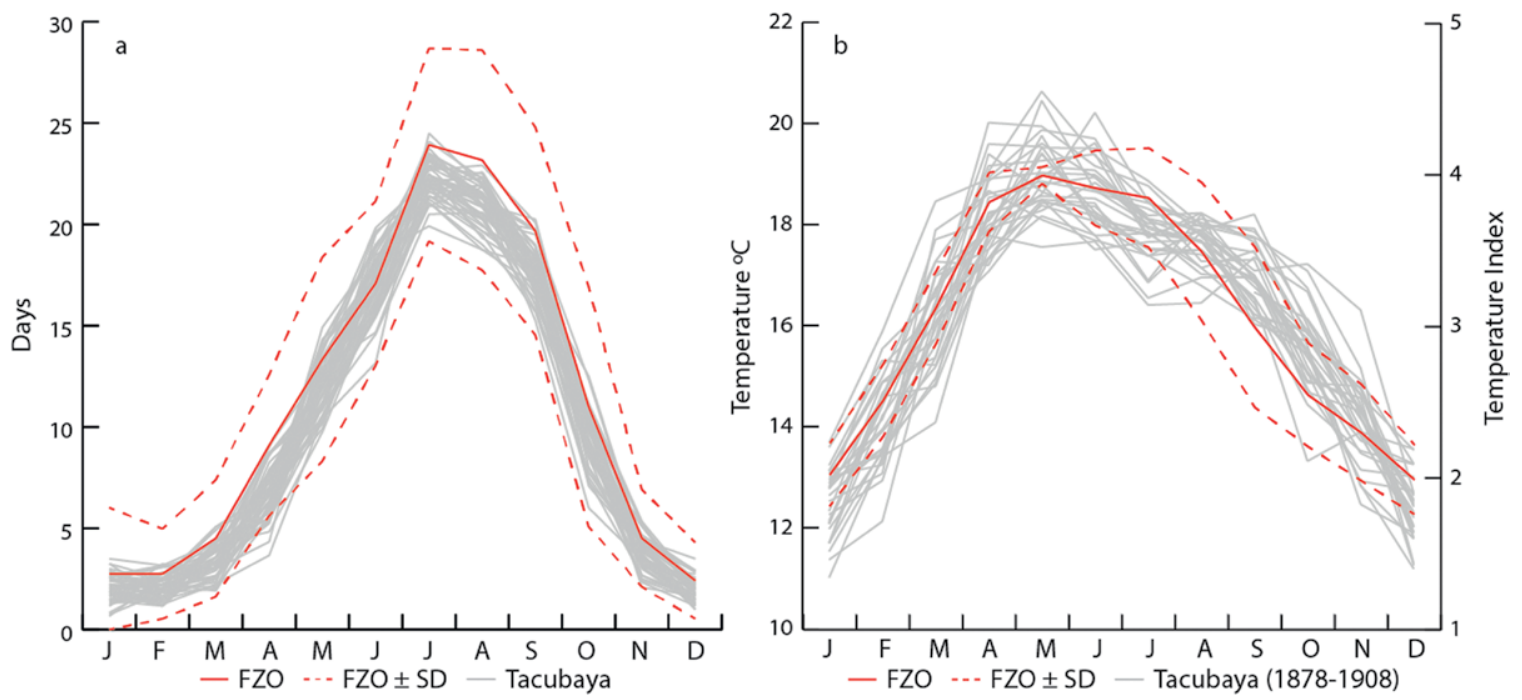

Fig. 3. (a) Mean annual cycle of the monthly frequency of rainy days (solid red line) and mean monthly frequency \pm I SD (dashed red lines) from FZO period (1775-86) and Tacubaya mean annual cycle of the monthly frequency of rainy days during 30 years (1878-1909; gray lines). (b) Monthly temperature index climatology (solid red line) and monthly temperature index \pm I SD (dashed red lines) for the FZO period (1775-86) and Tacubaya monthly mean temperature (gray lines); each gray line used for Tacubaya corresponds to a given year of the 1878-1909 period. 
1782/83 period, with 1776 being one of the wettest years, particularly in May and October, of the FZO period (Fig. 4c).

Temperature. The monthly temperature index for a specific month has been computed as the mean of the daily indices for this month. Moreover, we have computed the FZO annual cycle as the monthly means of each month during the FZO period (1775-86). Figure $3 \mathrm{~b}$ compared the FZO annual cycle (red line) with the 30 years of Tacubaya (1878-1908) (gray line). The temperature index shows a clear annual cycle, with maxima in May and June and minima during January and December. This annual cycle is very similar to that recorded in the Tacubaya temperature series. This indicates that the adjectives used by FZO are referring to temperatures rather than to temperature anomalies. This is important, because temperature records in weather diaries are often anomalies with respect to the contemporary climatology (Fernández-Fernández et al. 2014) (i.e., deviation with respect to the expected temperature). Therefore, the interpretation of temperature indices is very different in both cases.

To evaluate the interannual variability, we computed monthly anomalies of the temperature index considering the reference period 1775-86 (Fig. 4d). The coldest year was 1785 , when almost all months show negative anomalies, especially from July to November. The year 1778 was also cold with negative anomalies, mainly from June to August. On the other
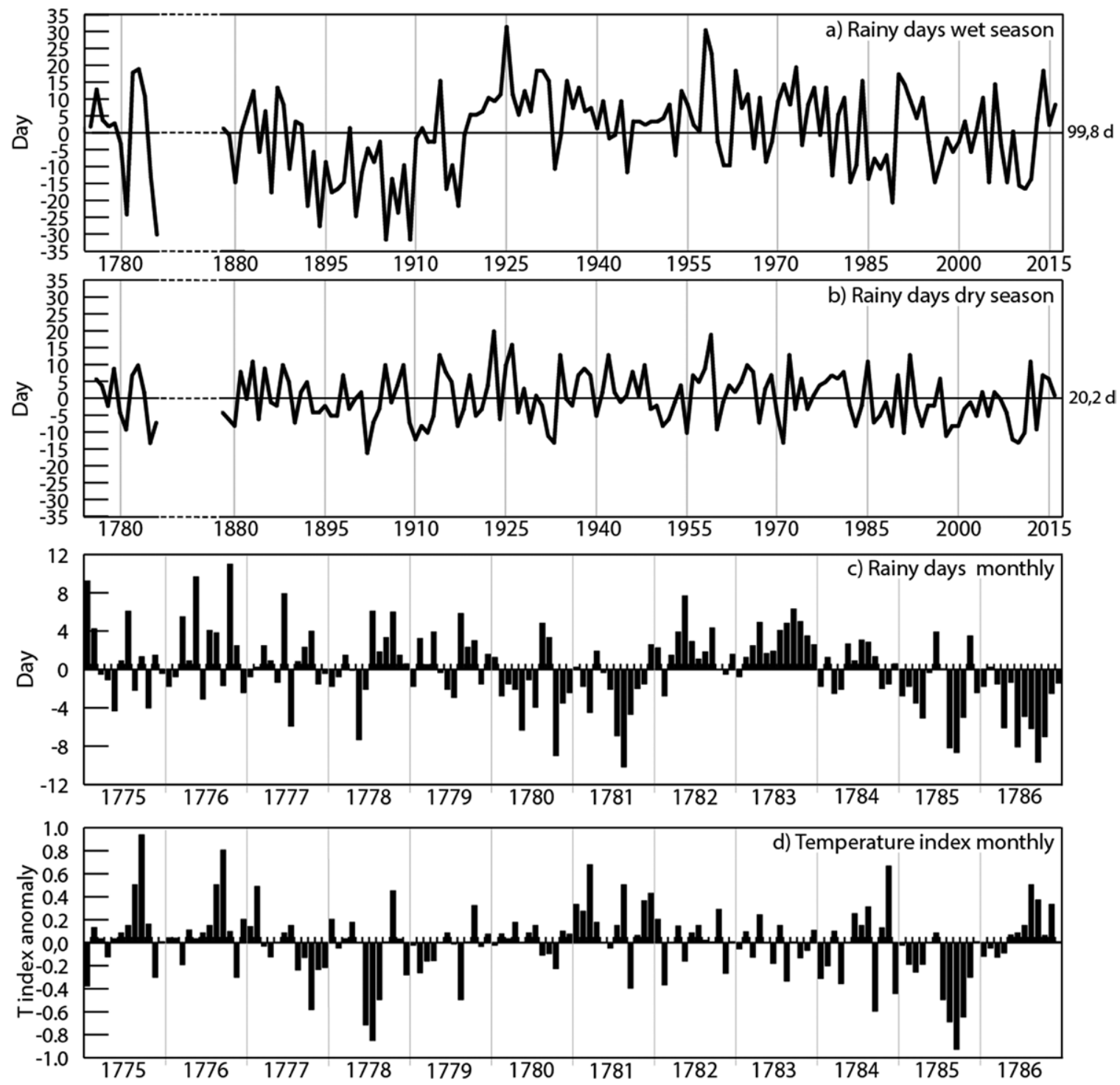

FIG. 4. Rainy day anomalies at Tacubaya (Observatory 1877-2006) during the (a) wet season (May-Oct) and (b) dry season (Nov-Apr). (c) Monthly anomalies of rainy days during the FZO period (1775-86) and (d) monthly temperature index anomalies during the FZO period. 
hand, 1781 is the warmest year with positive anomalies in all months except for June and August. The years 1775 and 1776 show a similar pattern, with high positive anomalies during August and September.

Hail, fog, thunderstorms, frost, and wind. Figure 5 shows the monthly frequencies of frost, hail, fog, thunderstorm, and wind during the FZO period. Tacubaya only records some of these events, namely, hail, fog, and thunderstorms. Figure 6 compares the average annual cycle of the monthly frequency of these events during the Tacubaya (1981-2016) and FZO (1775-86) periods. The monthly frequency of hail days has similar values and annual distribution
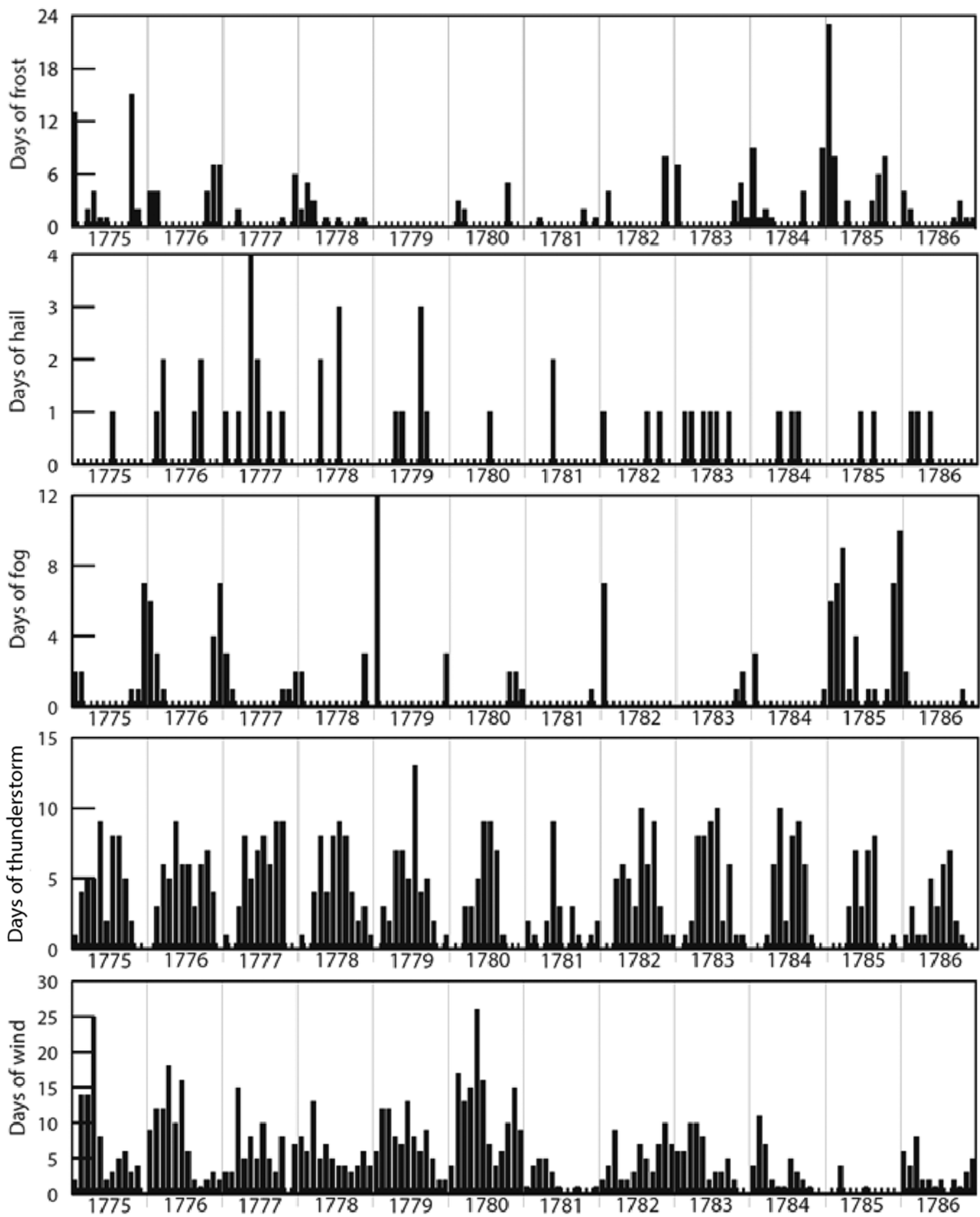

Fig. 5. Monthly frequency of days with (top to bottom) frost, hail, fog, thunderstorms, and wind in Mexico from 1775 to 1786. 
in both periods. Most of the events are concentrated during the wet season in both series. The main difference is that Tacubaya shows the maximum frequency in August, compared to May for FZO (Fig. 6). The highest record of hail days during the FZO period was in 1777 (10 days) (Fig. 5), a value
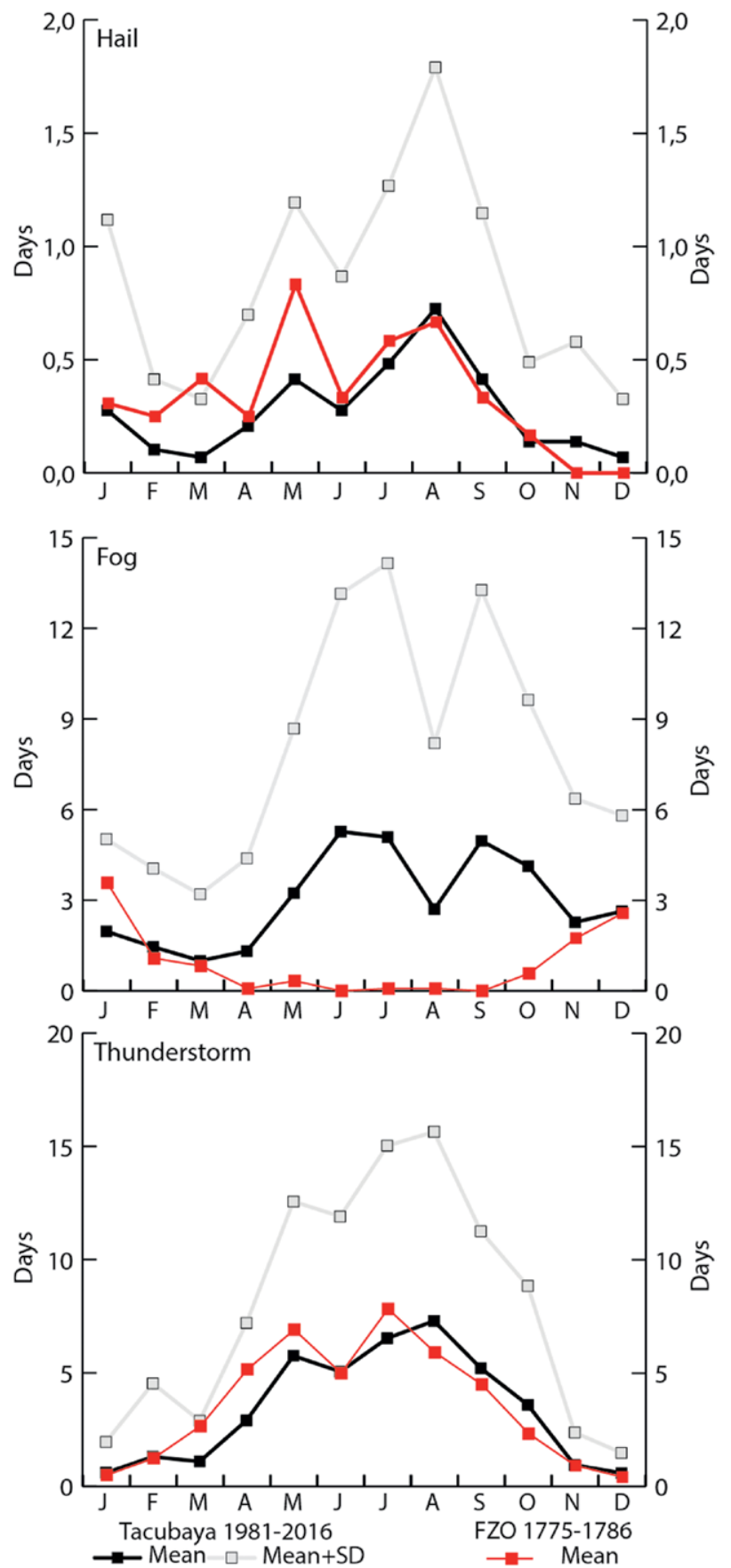

Fig. 6. Annual cycle, with statistical spread, of the monthly frequencies of hail, fog, and thunderstorm days during the FZO (1775-86; red) and Tacubaya (198I-2016; black for mean values and gray for mean + I SD) periods. that is only reached at Tacubaya in 1990 and 2015. It is also noteworthy that four of these days were recorded in May, with no analogs during the same month at Tacubaya.

The frequency of foggy days recorded by FZO is very low (11 days $\mathrm{yr}^{-1}$ ), compared to 23 days $\mathrm{yr}^{-1}$ at Tacubaya. Notably, the FZO seasonal distribution is opposite to the distribution during the Tacubaya period (Fig. 6). While the maximum number of foggy days in FZO is recorded during the dry season, it is observed at Tacubaya during the wet season. Fog is a meteorological phenomenon that can form in different ways, depending on how the cooling that caused the condensation occurred (i.e., radiation, advection, or frontal). In addition, its duration and times of occurrence are highly variable. All these factors together can affect the FZO observation. The fog climatology of the Mexico City metropolitan area shows some interesting characteristics (GarcíaGarcía and Zarraluqui 2008; González-Viveros et al. 2018). We can observe that the seasonal pattern recorded by FZO (i.e., more foggy days during the dry season than during the wet season and no foggy days from June to September) corresponds to the seasonal distribution of frontal fogs (associated with the passage of fronts and with the mixing of moist air parcels with different temperature). Recalling that frontal fog persists longer than radiative and advective fogs, with no preference of time for their occurrence unlike radiative fogs (i.e., early in the morning), we can assume that FZO recorded only frontal fogs. Moreover, the modern annual mean of frontal fog is almost 9 days, which is quite similar to the 11 days recorded by FZO. Anyway, we must take into account that the region has experienced important land-cover changes since the FZO period. The most important ones linked to the availability of low-level moisture are the Texcoco Lake system desiccation process (Gill 1996; Benson-Lira et al. 2016) and the heat island phenomenon. Both changes have probably affected the frequency of fogs. In any case, 1785 is the most anomalous year during FZO, because it is the only one with fog events during the wet season, and it is also by far the year with the most fog events (47 days, 4 times more than the annual mean during the FZO period) (Fig. 5).

The monthly frequency of thunderstorms is very similar at Tacubaya and FZO series (Fig. 6), and also to the distributions of rainy days, with maxima during the wet season and minima during the dry season. The annual mean is very similar: 41 thunderstorm days at Tacubaya and 43 days in FZO. The year with the most thunderstorm events was 1777 
(56 days), while the lowest frequency was reached in 1781 (24 days) (Fig. 5).

Most of the frost days occurred during the dry season (October-March) (Fig. 6), when temperatures are low (Fig. 3). Frosts appear during the wet season only in 1775 and 1785 . Their annual frequency is highly variable, ranging from 51 days in 1785 to 0 days in 1779 (Fig. 5).

In general, the notes about windy days in the FZO diary are more frequent in the first half of the year than in the second half. Moreover, these are also more frequent during 1775-80 (92 windy days $\mathrm{yr}^{-1}$ ) than from 1781 to 1786 (35 windy days $\mathrm{yr}^{-1}$ ) (Fig. 5). It is important to note that this coincides with the change of residence of FZO (July 1781), suggesting that the change in wind frequency is an inhomogeneity in the data rather than a modification of the wind regime. FZO described the wind as "turbulent hurricanes" twice: 8 May 1776 and 17 April 1779.

\section{THE HUNGER YEAR (EL AÑO DEL} HAMBRE): 1785/86. The hunger year is considered the worst famine in Mexico during the colonial period (1521-1821). It is difficult to provide exact dates of the start and end of the event. The most important social impacts started during the summer of 1785 and ended in autumn of 1787. Nevertheless, the climatic anomaly is centered in the two calendar years (i.e., 1785 and 1786). A combination of adverse climate, lack of food, and an outbreak of typhus epidemic killed around 300,000 people (Cooper 1965; Burns et al. 2014). A drought event extended over almost all the Mexican territory and was particularly severe over the central and northeastern regions (Stahle et al. 2016). This event was evidenced by tree-ring records (Therrell 2005; Therrell et al. 2006; Stahle et al. 2016). Documentary sources also reported a severe drought during 1785/86 and an early killing frost in 1785 (Florescano 1976, 1986; Swan 1981; Garza-Merodio 2002; García Acosta et al. 2003; Garza-Merodio 2017). Moreover, they described the social impact of the crisis and the initiatives taken by the government to deal with the crisis (Endfield and O'Hara 1997; Endfield 2007; Espinosa Cortés 2016). FZO's diary also provides information about these social conflicts. For example, on a marginal note from April 1786 (see quotation 2 in the online supplemental material for the original Spanish), it is reported that poverty reached the highest levels and was accompanied by epidemic fevers that impacted most of the families (de Zúñiga y Ontiveros 1786, p. 252). Also, it is evident that the city received numerous peasants who could not make a life in the countryside. This situation generated tensions in the city.
The mentioned studies agree that late precipitation and early killing frosts were the most important drivers of this crisis. Florescano (1986) indicated that the worst climatic conditions for the harvest during the colonial period occurred in the hunger year, highlighting the lack of precipitation during the sowing (April, May, and June), the prolongation of the drought during the next months, and the excess of precipitation or frost in August and September when the maturation progress is in its final stage.

Interestingly, $\mathrm{FZO}$ provides - for the first time-a daily meteorological record of the hunger year, which allows for an accurate comparison of the event with the instrumental climate. The period $1785 / 86$ was the driest of FZO, with only 188 rainy days. A similar record of low rainy days only occurred two times in the instrumental period: i) 1909/10 (188 days) and ii) 2010/11 (189 days). The 2010/11 drought episode was one of the most harmful in the country over the last decades, affecting $80 \%$ of the Mexican territory and producing losses of 16,000 million pesos only in the farming sector (Ortega-Gaucin 2018). Around 2.5 million Mexicans were left with insufficient drinking water (Seager et al. 2014), and forest fires hit record values $(956,405$ ha burned) (Zúñiga-Vásquez et al. 2019). The impact of the $1909 / 10$ drought is more difficult to assess, but according to the National Commission for the Hydrological Plan (Florescano 1980), it affected many regions. Specifically, crops were lost and 30,000 farm animals died because of the lack of water, particularly in Chihuahua.

To evaluate how anomalous the rainfall distribution during the hunger year was, the daily accumulated anomalies of rainy days are illustrated in Fig. 7a. The rainfall frequency during 1784 was very similar to the mean distribution of rainy days during 1877-2016, with accumulated anomalies of \pm 6 days. The picture during 1785 is very different, as the accumulated deficit of rainy days increased throughout year, except from 24 May to 26 July and from 19 October to 19 November. The beginning of the year was very dry, with only two rainfall days from 1 January to 19 April 1785 (the mean of the instrumental period is 11.58 days, and the standard deviation is 5.45 days). However, the frequency of rainy days (58 days) during the first half of the wet season (May-July) was above the mean of the instrumental period (51 days), but precipitation during the second half (August-October) was low (32 days in 1785 , compared to the mean value of 48 days in the instrumental period). The FZO diary clarifies that 1785 was a dry year, but with a normal frequency of rainy days during the corn growing season (April-June). This is interesting because it 
contradicts previous evidence that May and June were completely dry (Espinosa Cortés 2016). On the other hand, the FZO diary firmly supports that early frosts caused harvest losses. Figure 8 shows the daily distribution of frost days during the period 1784-86. During 1785, frost events happened on 12, 13, and 14 April. However, FZO does not highlight any damage to the crops, probably because cops were not growing because of the lack of rain. However, the margin notes on the manuscript indicate that the damages of the early frost happened on 26, 27, and 28 August and 2, 3, 4, 23, 24, and 25 September:

2 September: "The frosts have done great damage during the sown, this has raised the price of the supplies excessively... not by the lack of them" (de Zúñiga y Ontiveros 1786, p. 233) (see quotation 3 in the online supplemental material for the original Spanish).

4 September: "There has been frost, and the fruits of corn, bean, broad bean and others which were green have been lost. We expect a notable scarcity in the future. There was some recovery with the previous precipitation, but everything has been lost with the frost" (de Zúñiga y Ontiveros 1786, p. 233) (see quotation 4 in the online supplemental material for the original Spanish).

23 September: "Frosts again and they were serious frosts" (de Zúñiga y Ontiveros 1786, p. 233) (see quotation 5 in the online supplemental material for the original Spanish).

24 September: "There has been frost these days and this has finished with the few fruits that were left, anticipating much need. The frosts have been almost general" (de Zúñiga y Ontiveros 1786, p. 233) (see quotation 6 in the online supplemental material for the original Spanish).

In summary, FZO records how the frost destroyed all the crops and how the expectation of no harvest
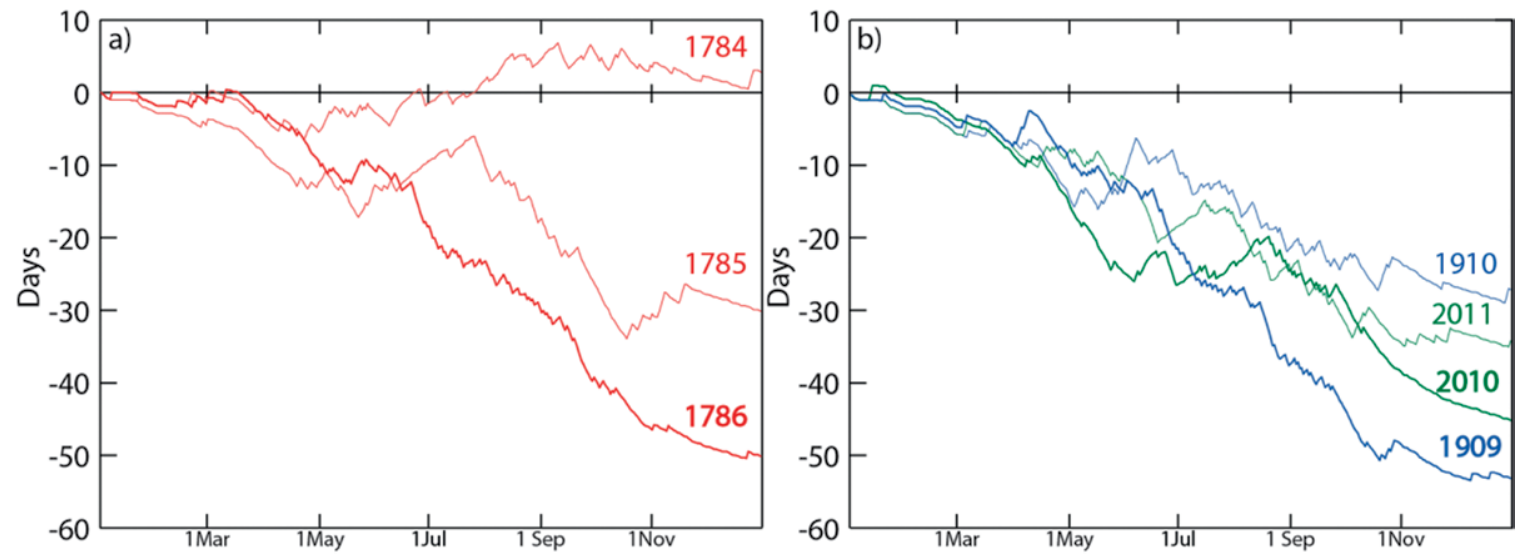

Fig. 7. Accumulated rainy-day anomalies (reference period: 1877-2016): (a) 1784, 1785, and 1786 and (b) 1909, 1910, 2010, and 2011 . produced an increase of prices during the end of August and September. Moreover, during October, the frost continued, but everything was lost. The footnote on the October page reads: "the frosts since August 28th have been so general that the fruits have been lost throughout the Kingdom, with the exception of the warm lands; the government has asked them to sow corn, beans and other seeds in the irrigated lands immediately so that they can be harvested by March 1786 and partially remedy the hunger that threatens" (de Zúñiga y Ontiveros 1786, p. 234) (see quotation 7 in the online supplemental material for the original Spanish).

The number and distribution of frost days in 1785 were very unusual in comparison with the rest of the FZO period (Fig. 5a). Unfortunately, frosts were not recorded at Tacubaya station, making it difficult to compare this record with the instrumental period. Although we stressed the problems of the Tacubaya temperature series (e.g., gaps and land-use changes), we provide some features of the distribution of days with temperatures $\leq 0^{\circ} \mathrm{C}$ during the period $1878-2016$ : i) only $0.4 \%$ of the days show minimum temperatures $\leq 0^{\circ} \mathrm{C}$, ii) the lowest temperature recorded in August is $+1.5^{\circ} \mathrm{C}$, iii) the earliest date with temperature $\leq 0^{\circ} \mathrm{C}$ is on 7 September (1922), and iv) minimum temperature has been above $0^{\circ} \mathrm{C}$ since 1986 . Taking all this into consideration, it seems that the frost during 1785 was also extreme in comparison with the instrumental period. In summary, although 1785 was a dry year, the distribution of precipitation did not cause much damage to crops. However, the early and generalized frost in August that extended until October killed the crops.

The main characteristic during 1786 was the extremely severe drought. As can be seen in Fig. 7a, the accumulated negative anomaly increased consistently 


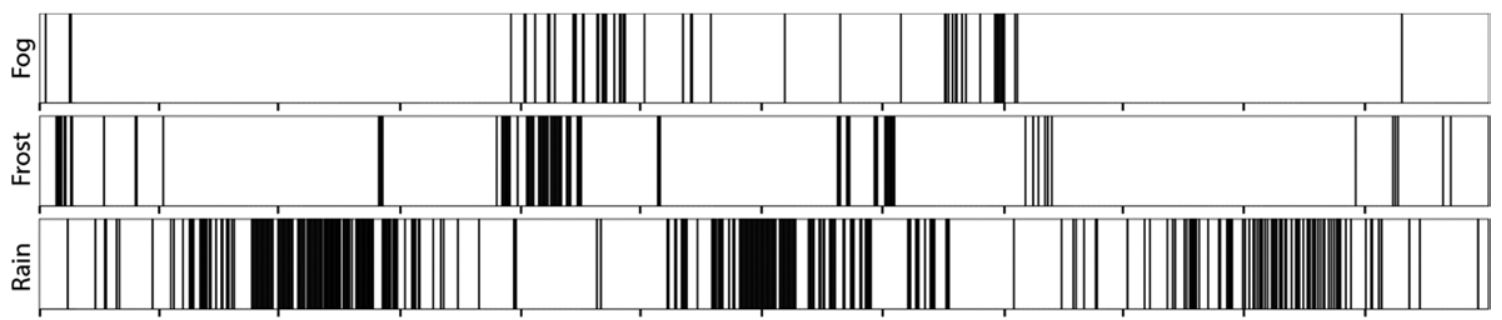

$\begin{array}{llllllllllll}1 / 1 / 1784 & 1 / 4 / 1784 & 1 / 7 / 1784 & 1 / 10 / 1784 & 1 / 1 / 1785 & 1 / 4 / 1785 & 1 / 7 / 1785 & 1 / 10 / 1785 & 1 / 1 / 1786 & 1 / 4 / 1786 & 1 / 7 / 1786 & 1 / 10 / 1786\end{array}$

Fig. 8. Daily distribution of frost, foggy, and rainy days during the period 1784-86.

during the year, except in May when precipitation was similar to the instrumental mean in that month. This situation impeded the growing of any crop. The annual summary of FZO for 1786 was, "It has been an unfortunate year due to scarcity of rain, supplies and everything needed for life, also in misfortune and public diseases" (de Zúñiga y Ontiveros 1786, p. 272) (see quotation 8 in the online supplemental material for the original Spanish). Figure $7 \mathrm{~b}$ compares the FZO drought duration with that of the instrumental period, indicating the daily accumulated anomalies of rainy days for the droughts of 1909/10 and $2010 / 11$. The $1909 / 10$ drought is similar to the $1785 / 86$ drought. In particular, 1909 has similar distribution to that of 1786 , with a continuous lack of precipitation that generated a deficit of around 50 precipitation days at the end of the year. On the other hand, 1910 is similar to 1785 , with a generalized increase in the accumulated negative anomalies during the whole year, except during the growing season (May-June), with a deficit around 30 days at the end of the year. The pattern in 2010 was similar to that of 1785 and 1910, also with a continuous increase in the accumulated negative anomalies except during some short periods in the growing season, in this case from 7 June to 29 August. During 2011, the deficit of rainy days increased almost continuously during the whole year. Overall, the drought conditions during the hunger year seem analogous to those recorded in the two most severe droughts of the instrumental period.

POSSIBLE CAUSES FOR UNUSUAL CLIMATE CONDITIONS IN MEXICO CITY DURING THE HUNGER YEAR. Some authors have hypothesized that the anomalous climate during the hunger year was related to the Icelandic Laki volcano eruption (Endfield et al. 2004; Therrell 2005). That eruption $\left(64.10^{\circ} \mathrm{N}, 17.15^{\circ} \mathrm{W}\right)$ started in June 1783 and continued until February 1784 but with periods of different activity, producing a huge volume of lava and tephra $(15.1 \pm 1.0 \mathrm{~km})$ as well as sulfur dioxide $\left(\mathrm{SO}_{2}\right)$ emissions (122 Mt) (Thordarson et al. 1996;
Thordarson and Self 2003). Large volcanic eruptions release gases into the atmosphere that reduce the solar radiation reaching the surface. These changes in radiation during large tropical volcanic explosive eruptions have impacts on the main climate modes as the North Atlantic Oscillation (NAO) or El NiñoSouthern Oscillation (ENSO) (Swingedouw et al. 2017). Although the climate modification of highlatitude eruptions (as Laki) have been considered low, some recent works suggest that the climate impact of the extratropical volcanic eruptions could be greater than expected until now, affecting the main climate modes and producing stronger hemispheric cooling than tropical eruptions (Pausata et al. 2015; Büntgen et al. 2016; Toohey et al. 2019).

Since it is not possible to attribute the hunger years to the Laki eruption only from the FZO record, we have analyzed other evidences to try to understand the possible impacts of the Laki eruption on NAO and ENSO.

The NAO shows imprints in Europe and the eastern coast of the United States (Hurrell et al. 2013). The winter $1783 / 84$ was particularly cold in different parts of Europe and in the northeastern United States (Písek and Brázdil 2006). The cold conditions over central and northern Europe have been documented by previous studies (Bergström and Moberg 2002; Jones and Lister 2002; Moberg et al. 2002; Yiou et al. 2014; Przybylak et al. 2014). This was the sixth coldest winter in Prague since 1775 (Písek and Brázdil 2006), and one of the coldest winters in France and northern Italy over the last 500 years (Camuffo et al. 2010). Nevertheless, the winter was mild in southern Europe. In Zafra (southwest of Spain), only 15\% of the weeks were defined as colder than usual in the weather descriptions of the accountant of the Duke of Feria when the winter mean for the period 1750-1840 is $40 \%$ (Fernández-Fernández et al. 2017). However, the winter was very wet in southern Europe. For instance, it was one of the wettest winters in Barcelona in the last 500 years (Camuffo et al. 2010) and Zafra (in the period 1750-1840) (Fernández-Fernández 
et al. 2015). But also dry conditions dominated northern Europe (Alexander and Jones 2001; Murphy et al. 2018). FZO was aware of the cold conditions on both sides of the Atlantic and wrote this for winter 1783/84: "In May we had news from Spain saying that this winter has been so severe in Europe that even the main rivers, such as the Danube, were frozen in many places. There were many cold-induced livestock losses and some of these conditions have reached this kingdom, as will be noted in the diaries" (de Zúñiga y Ontiveros 1786, p. 210) (see quotation 9 in the online supplemental material for the original Spanish). The cold anomalies in central and northern Europe and the eastern United States continued during 1785 and 1786 (Thordarson and Self 2003; Xoplaki et al. 2005; Brázdil et al. 2017). The influence of the Laki eruption in this anomalous climate continues to be under discussion. Some authors propose that the unusual climate is due to natural variability by a combined negative NAO phase and ENSO warm event (D'Arrigo et al. 2011). Others consider that the Laki forcing played a role (Schmidt et al. 2012) but the mechanisms are not yet well understood. In any case, to the best of our knowledge, there are no reported relevant teleconnections between the climate in Mexico City and NAO.

We have also examined a possible ENSO influence. However, while drought conditions in northern Mexico are well studied and show a high, significant, and stable correlation with the cold phases of ENSO (Mason and Goddard 2001; Magaña et al. 2003), drought conditions in central Mexico do not show a clear correlation. Some La Niña events have produced dry conditions in the northern and central region of Mexico, for example, 1890, 1893, 1894, 1910, 1917, 1951, 1971 (Stahle et al. 2016), or 2011 (Seager et al. 2014). Nevertheless, there are extreme La Niña events that have restricted dry conditions to the northern region, for example, 1887, 1904, 1934, 1956, or 1974 (Stahle et al. 2016). But the mechanisms that expand southward the dry conditions are unclear. Weak to moderate El Niño events occurred in 1783 and 1784; the situation changed in 1785 with a weak La Niña event that was reinforced to a strong La Niña event in 1786 (Gergis and Fowler 2009). These La Niña events probably triggered the drought in northern Mexico, as occurred in 1909/10 (Stahle et al. 2016) and 2010/11 (Seager et al. 2014). However, it is speculative to attribute the drought in Mexico City to this factor as we have explained. Probably, internal atmospheric variability unrelated to ocean conditions or local land-atmosphere interactions were important factors to expand the drought southward. About the possible relation of these ENSO phases with the Laki eruption, Pausata et al. (2015) have proposed that high-latitude eruptions can induce an El Niño anomaly during 8-9 months after the eruption. So it is probable that El Niño events in 1783 and 1784 were influenced by the Laki eruption. However, it seems difficult to identify a plausible mechanism linking La Niña conditions during the hunger year (more than a year after the eruption) with the Laki eruption.

In summary, the evidences are inconclusive to link the eruption and the hunger years. Nevertheless, it is possible that FZO recorded the footprint of the Laki eruption on his weather diary as a clear increase of foggy days in 1785 (more than 4 times the annual mean recorded during the FZO period) (Fig. 8). It is possible that these events were related to the increase in aerosols and therefore cloud condensation nuclei being injected in the atmosphere during the eruption (Schmidt et al. 2010), although some studies disregard this possibility because of the date (more than a year after the eruption) or the location (below $30^{\circ} \mathrm{N}$ ) (Chenet et al. 2005; Oman et al. 2006b). On the other hand, Trigo et al. (2010) proposed a possible association of the strange fog events recorded by Bento Sanches Dorta in Rio de Janeiro during 1784-86 and the Laki eruption. Similarly, Oman et al. $(2005,2006 a)$ suggested global impacts of very large high-latitude eruptions. Moreover, the total $\mathrm{SO}_{4}$ deposition during the year following the eruption, averaged from the three simulations of the volcanic aerosol cloud from Oman et al. (2006b) (provided in Schmidt et al. 2012), shows a deposition around $400 \mathrm{~kg} \mathrm{~km}^{-2}$ in Mexico City. This value is similar to other places where the volcanic haze was documented as western Greenland, Lisbon, Tripoli, or Altai Mountains (Thordarson and Self 2003). For this last reason, we think that the increase of foggy days during 1785 was likely influenced by the Laki eruption.

CONCLUDING REMARKS. The weather diary of Felipe de Zúñiga y Ontiveros is the earliest observational record retrieved and studied in Mexico. It provides daily meteorological information from 1 January 1775 to 31 December 1786 for rain frequency, temperature, frost, hail, thunderstorms, and windy days, with higher resolution than any other contemporary document or natural proxy in the region. We have shown that most of the information provided by the diary is directly comparable with information provided by the instrumental record (frequency of rain, hail, and thunderstorm). Furthermore, the 
temperature, wind, frost, or fog writings allow for better understanding of the climate variability during the 12 years covered by this diary.

The seasonal distributions of rainy days, temperature, hail, and thunderstorms correspond well with those from the Tacubaya Observatory. Nonetheless, FZO seems to have a higher number of precipitation days in the peak of the rainy season from June to August. According to FZO, 1785 and 1778 were the coldest years, while 1781 was the warmest one. Two drought periods (1780/81 and 1785/86) and one wet period (1782/83) were also identified.

The FZO record provides a detailed picture of the hunger year (1785/86). It shows that 1785 was a cold and very dry year. These dry conditions were combined with intense frosts that started in late August and continued through September and October. This combination led to the loss of crops and subsequent famine. The drought during 1786 was more intense than in 1785. Similar drought conditions to those in 1785/86 were recorded in 1909/10 and 2010/11. Nevertheless, the frost pattern has no analog in the instrumental period.

Overall, we evidenced that 1785 was the most anomalous year of the FZO record, being very dry, cold, and foggy. These characteristics could possibly be linked to the Laki eruption (1783/84) on Iceland, although the evidences are inconclusive to link the eruption and the hunger year.

ACKNOWLEDGMENTS. The authors are very grateful to Ana Gavilán and César Paradinas for their help with the transcription of the FZO weather diary. Carlos Ordóñez reviewed the language. This work was supported by the research projects IMDROFLOOD financed by the Water Works 2014 cofunded call of the European Commission and INDECIS, which is part of ERA4CS, an ERA-NET initiated by JPI Climate by the European Union (Grant 690462). Marina Peña-Gallardo was granted by the Spanish Ministry of Economy and Competitiveness (MINECO), and Ahmed El Kenawy was supported by a postdoctoral Juan de la Cierva contract by the Spanish Ministry of Economy and Competitiveness (MINECO).

\section{REFERENCES}

Acosta-Hernández, A. C., M. Pompa-García, and J. J. Camarero, 2017: An updated review of dendrochronological investigations in Mexico, a megadiverse country with a high potential for tree-ring sciences. Forests, 8, 160, https://doi.org/10.3390/f8050160.

Alexander, L. V., and P. D. Jones, 2001: Updated precipitation series for the U.K. and discussion of recent extremes. Atmos. Sci. Lett., 1, 142-150, https://doi .org/10.1006/asle.2001.0025.

Allan, R., P. Brohan, G. P. Compo, R. Stone, J. Luterbacher, and S. Brönnimann, 2011: The international Atmospheric Circulation Reconstructions over the Earth (ACRE) Initiative. Bull. Amer. Meteor. Soc., 92, 1421-1425, https://doi.org/10.1175 /2011BAMS3218.1.

Alzate, J. A., 1831: Gacetas de literatura de Mexico. Vol. IV. Manuel Buen Abad, 446 pp.

Baron, W. R., 1982: The reconstruction of eighteenth century temperature records through the use of content analysis. Climatic Change, 4, 385-398, https:// doi.org/10.1007/BF02423470.

Benson-Lira, V., M. Georgescu, S. Kaplan, and E. R. Vivoni, 2016: Loss of a lake system in a megacity: The impact of urban expansion on seasonal meteorology in Mexico City. J. Geophys. Res. Atmos., 121, 3079-3099, https://doi.org/10.1002/2015JD024102.

Bergström, H., and A. Moberg, 2002: Daily air temperature and pressure series for Uppsala (17221998). Climatic Change, 53, 213-252, https://doi .org/10.1023/A:1014983229213.

Bernhardt, J., 2015: Determining regional weather patterns from a historical diary. Wea. Climate Soc., 7, 295-308, https://doi.org/10.1175/WCAS -D-15-0016.1.

Brázdil, R., and O. Kotyza, 1996: The earliest daily weather records in the Czech lands and their utilisation for the reconstruction of climate. Weather, 51, 341-349, https://doi.org/10.1002/j.1477-8696.1996 .tb06154.x.

— - T. Černušák, and L. Řezníčková, 2008: Weather information in the diaries of the Premonstratensian Abbey at Hradisko, in the Czech Republic, 16931783. Weather, 63, 201-207, https://doi.org/10.1002 /wea.264.

— , P. Dobrovolný, J. Luterbacher, A. Moberg, C. Pfister, D. Wheeler, and E. Zorita, 2010: European climate of the past 500 years: New challenges for historical climatology. Climatic Change, 101, 7-40, https://doi.org/10.1007/s10584-009-9783-z.

— , P. Zahradníček, P. Pišoft, P. Štěpánek, M. Bělínová, and P. Dobrovolný, 2012: Temperature and precipitation fluctuations in the Czech Republic during the period of instrumental measurements. Theor. Appl. Climatol., 110, 17-34, https://doi.org/10.1007/s00704 -012-0604-3.

—, L. Řezníčková, H. Valášek, L. Dolák, and O. Kotyza, 2017: Climatic and other responses to the Lakagígar 1783 and Tambora 1815 volcanic eruptions in the Czech lands. Geografie, 122, 147-168, www .geografie.cz/en/archive/download/11. 
Brenner, M., D. A. Hodell, J. H. Curtis, M. F. Rosenmeier, F. S. Anselmetti, and D. Ariztegui, 2003: Paleolimnological approaches for inferring past climate change in the Maya region. Recent advances and methodological limitations. The Lowland Maya Area: Three Millennia at the Human-Wildland Interface, Haworth Press, 45-75.

Büntgen, U., and Coauthors, 2016: Cooling and societal change during the Late Antique Little Ice Age from 536 to around 660 AD. Nat. Geosci., 9, 231-236, https://doi.org/10.1038/ngeo2652.

Burns, J. N., R. Acuna-Soto, and D. W. Stahle, 2014: Drought and epidemic typhus, central Mexico, 1655 1918. Emerging Infect. Dis., 20, 442-447, https://doi .org/10.3201/eid2003.131366.

Butzer, K. W., and E. K. Butzer, 1993: The sixteenthcentury environment of the central Mexican Bajio: Archival reconstruction from colonial land grants and the question of ecological impact. Culture, Form, and Place, K. Mathewson, Ed., Louisiana State University Press, 89-124.

Camuffo, D., and P. Jones, 2002: Improved Understanding of Past Climatic Variability from Early Daily European Instrumental Sources. D. Camuffo and P. D. Jones, Eds., Kluwer Academic, 392 pp.

— construction in the Mediterranean Basin by means of documentary data and instrumental observations. Climatic Change, 101, 169-199, https://doi .org/10.1007/s10584-010-9815-8.

Chenet, A. L., F. Fluteau, and V. Courtillot, 2005: Modelling massive sulphate aerosol pollution, following the large 1783 Laki basaltic eruption. Earth Planet. Sci. Lett., 236, 721-731, https://doi.org/10.1016/j .epsl.2005.04.046.

Cooper, D. B., 1965: Epidemic Disease in Mexico City, 1761-1813. University of Texas Press, $250 \mathrm{pp}$.

D’Arrigo, R. D., R. Seager, J. E. Smerdon, A. LeGrande, and E. R. Cook, 2011: The anomalous winter of 1783-1784: Was the Laki eruption or an analog of the 2009-2010 winter to blame? Geophys. Res. Lett., 38, L05706, https://doi.org/10.1029/2011GL046696.

de Zúñiga y Ontiveros, F., 1786: Ephemérides astronómicas calculadas al meridiano de México, años 1775-1786. National Library of Spain, 272 pp., http:// bdh-rd.bne.es/viewer.vm?id=0000129888\&page $=1$.

Domínguez-Castro, F., R. García-Herrera, P. Ribera, and M. Barriendos, 2010: A shift in the spatial pattern of Iberian droughts during the 17th century. Climate Past, 6, 553-563, https://doi.org/10.5194 /cp-6-553-2010.

—, J. M. Vaquero, F. S. Rodrigo, A. M. M. Farrona, M. C. Gallego, R. García-Herrera, M. Barriendos, and A. Sanchez-Lorenzo, 2014: Early Spanish meteorological records (1780-1850). Int. J. Climatol., 34, 593-603, https://doi.org/10.1002/joc.3709.

—, R. García-Herrera, and J. M. Vaquero, 2015: An early weather diary from Iberia (Lisbon, 1631-1632). Weather, 70, 20-24, https://doi.org/10.1002/wea.2319.

— cords from Latin-America and the Caribbean during the 18th and 19th centuries. Sci. Data, 4, 170169, https://doi.org/10.1038/sdata.2017.169.

—, M. C. Gallego, and J. M. Vaquero, 2017b: Sunspots sketches during the solar eclipses of 9th January and 29th December of 1777 in Mexico. J. Space Wea. Space Climate, 7, A15, https://doi.org/10.1051 /swsc/2017012.

—, R. García-Herrera, and S. M. Vicente-Serrano, 2018: Wet and dry extremes in Quito (Ecuador) since the 17th century. Int. J. Climatol., 38, 2006-2014, https://doi.org/10.1002/joc.5312.

Eisinger, E. C., 1954: The farmer in the eighteenth century almanac. Agric. Hist., 28, 107-112.

Endfield, G. H., 2007: Archival explorations of climate variability and social vulnerability in colonial Mexico. Climatic Change, 83, 9-38, https:/doi .org/10.1007/s10584-006-9125-3.

—, and S. L. O'Hara, 1997: Conflicts over water in "the Little Drought Age" in central Mexico. Environ. Hist., 3, 255-272, https://doi.org/10.3197 /096734097779555863.

_ I. F. Tejedo, and S. L. O’Hara, 2004: Drought and disputes, deluge and dearth: Climatic variability and human response in colonial Oaxaca, Mexico. J. Hist. Geogr., 30, 249-276, https://doi.org/10.1016 /S0305-7488(03)00023-9.

Espinosa Cortés, L. M., 2016: “The year of hunger” in new Spain, 1785-1786: Corn shortage, epidemics and "public kitchens" for the poor (in Spanish). Diálogos Rev. Hist., 17, 159-180.

Fernández-Fernández, M. I., M. C. Gallego, F. Domínguez-Castro, R. M. Trigo, J. A. García, J. M. Vaquero, J. M. M. González, and J. C. Durán, 2014: The climate in Zafra from 1750 to 1840: History and description of weather observations. Climatic Change, 126, 107-118, https://doi.org/10.1007 /s10584-014-1201-5.

,,,---- , and J. M. Vaquero, 2015: The climate in Zafra from 1750 to 1840: Precipitation. Climate Change, 129, 267-280, https://doi .org/10.1007/s10584-014-1315-9.

- — - — - _ and - 2017: The climate in Zafra from 1750 to 1840: Temperature indexes from documentary sources. Climatic Change, 141, 671-684, https://doi.org/10.1007/s10584-017-1910-7. 
Fiebrich, C. A., 2009: History of surface weather observations in the United States. Earth Sci. Rev., 93, 77-84, https://doi.org/10.1016/j.earscirev.2009.01 .001 .

Florescano, E., 1976: Origen y Desarrollo de los Problemas Agrarios de Mexico 1500-1821. Ediciones Era, 158 pp.

— 1980: Análisis Históricos de las Sequías en México. Comision del Plan Nacional Hidráulico, 158 pp.

— 1986: Precios del Maíz y Crisis Agrícolas en México: 1708-1810. Ediciones Era, 236 pp.

García Acosta, V., J. M. Pérez Zevallos, and A. Molina del Villar, 2003: Época Prehispánica y Colonia (9581822). Vol. I, Desastres Agrícolas en México: Catálogo Histórico, Centro de Investigaciones y Estudios en Antropología Social, 506 pp.

García-García, F., and V. Zarraluqui, 2008: A fog climatology for Mexico. Erde, 139, 45-60.

García-Herrera, R., D. Barriopedro, D. Gallego, J. Mellado-Cano, D. Wheeler, and C. Wilkinson, 2018: Understanding weather and climate of the last 300 years from ships' logbooks. Wiley Interdiscip. Rev.: Climate Change, 9, e544, https://doi.org/10.1002 /wcc. 544.

Garza-Merodio, G. G., 2002: Frecuencia y duración de sequías en la cuenca de México de fines del siglo XVI a mediados del XIX. Invest. Geogr., 48, 106-115.

_ 2014: Caracterización de la Pequeña edad de Hielo en el México central a través de fuentes documentales. Invest. Geogr., 85, 82-94.

— , 2017: Variabilidad Climática en México a Través de Fuentes Documentales (Siglos XVI al XIX). Universidad Nacional Autónoma de México Instituto de Geografía, 147 pp.

Gergis, J. L., and A. M. Fowler, 2009: A history of ENSO events since A.D. 1525: Implications for future climate change. Climatic Change, 92, 343-387, https:// doi.org/10.1007/s10584-008-9476-z.

Gill, T. E., 1996: Eolian sediments generated by anthropogenic disturbance of playas: Human impacts on the geomorphic system and geomorphic impacts on the human system. Geomorphology, 17, 207-228, https://doi.org/10.1016/0169-555X(95)00104-D.

González-Viveros, P., E. Caetano, and F. García-García, 2018: Characterization and modeling of fog in the Mexico basin. Aerosol Air Qual. Res., 18, 79-90, https://doi.org/10.4209/aaqr.2016.12.0548.

Hodell, D. A., and Coauthors, 2012: Late Glacial temperature and precipitation changes in the lowland neotropics by tandem measurement of $\delta^{18} \mathrm{O}$ in biogenic carbonate and gypsum hydration water. Geochim. Cosmochim. Acta, 77, 352-368, https://doi .org/10.1016/j.gca.2011.11.026.
Hurrell, J. W., Y. Kushnir, G. Ottersen, and M. Visbeck, 2013: An overview of the North Atlantic Oscillation. The North Atlantic Oscillation: Climatic Significance and Environmental Impact, Geophys. Monogr., Vol. 134, Amer. Geophys. Union, 1-35.

Jauregui, E., 1997: Heat island development in Mexico City. Atmos. Environ., 31, 3821-3831, https://doi .org/10.1016/S1352-2310(97)00136-2.

Jones, P. D., and D. H. Lister, 2002: The daily temperature record for St. Petersburg (1743-1996). Climatic Change, 53, 253-268, https://doi.org/10.1023 /A:1014918808741.

Lisboa, J. L., 1989: Popular knowledge in the 18th century almanacs. Hist. Eur. Ideas, 11, 509-513, https:// doi.org/10.1016/0191-6599(89)90237-4.

Maejima, I., 1966: Some remarks on the climatic conditions of Kyoto during the period from 1474 to 1533 A.D. Geogr. Rep. Tokyo Metrop. Univ., 1, 103-111.

Magaña, V. O., J. L. Vázquez, J. L. Pérez, and J. B. Pérez, 2003: Impact of El Niño on precipitation in Mexico. Geofis. Int., 42, 313-330.

Mason, J., and L. Goddard, 2001: Probabilistic precipitation anomalies associated with ENSO. Bull. Amer. Meteor. Soc., 82, 619-638, https://doi.org /10.1175/1520-0477(2001)082<0619:PPAAWE >2.3 .CO;2.

Matsumoto, M., and T. Nishimura, 1998: Mersenne twister: A 623-dimensionally equidistributed uniform pseudo-random number generator. $A C M$ Trans. Model. Comput. Simul., 8, 3-30, https://doi .org/10.1145/272991.272995.

Medina-Elizalde, M., and E. J. Rohling, 2012: Collapse of classic Maya civilization related to modest reduction in precipitation. Science, 335, 956-959, https:// doi.org/10.1126/science.1216629.

Mendoza, B., E. Jáuregui, R. Diaz-Sandoval, V. GarcíaAcosta, V. Velasco, and G. Cordero, 2005: Historical droughts in central Mexico and their relation with El Niño. J. Appl. Meteor., 44, 709-716, https://doi .org/10.1175/JAM2210.1.

—, V. García-Acosta, V. Velasco, E. Jáuregui, and R. Díaz-Sandoval, 2007: Frequency and duration of historical droughts from the 16th to the 19th centuries in the Mexican Maya lands, Yucatan Peninsula. Climatic Change, 83, 151-168, https://doi .org/10.1007/s10584-006-9232-1.

Merodio, G. G. G., 2007: Climatología histórica: Las ciudades Mexicanas ante la sequía (siglos XVII al XIX) (Historical climatology: Facing drought in Mexican cities from the 17 th to the 19 th century). Invest. Geogr., 63, 77-92.

Metzger, A., and M. Tabeaud, 2017: Reconstruction of the winter weather in east Friesland at the turn 
of the sixteenth and seventeenth centuries (15941612). Climatic Change, 141, 331-345, https://doi .org/10.1007/s10584-017-1903-6.

Mikami, T., 1993: Summer temperature variabilities in Japan reconstructed from diary weather records during the Little Ice Age. J. Geog., 102, 144-151, https:// doi.org/10.5026/jgeography.102.2_144.

Moberg, A., H. Bergström, J. R. Krigsman, and O. Svanered, 2002: Daily air temperature and pressure series for Stockholm (1756-1998). Climatic Change, 53, 171-212, https://doi.org/10.1023/A:1014966724670.

Mock, C. J., J. Mojzisek, M. McWaters, M. Chenoweth, and D. W. Stahle, 2007: The winter of 1827-1828 over eastern North America: A season of extraordinary climatic anomalies, societal impacts, and false spring. Climatic Change, 83, 87-115, https://doi.org /10.1007/s10584-006-9126-2.

Murphy, C., and Coauthors, 2018: A 305-year continuous monthly rainfall series for the island of Ireland (1711-2016). Climate Past, 14, 413-440, https://doi .org/10.5194/cp-14-413-2018.

Oman, L., A. Robock, G. Stenchikov, G. A. Schmidt, and R. Ruedy, 2005: Climatic response to high-latitude volcanic eruptions. J. Geophys. Res., 110, D13103, https://doi.org/10.1029/2004JD005487.

,,--- , and T. Thordarson, 2006a: Highlatitude eruptions cast shadow over the African monsoon and the flow of the Nile. Geophys. Res. Lett., 33, L18711, https://doi.org/10.1029/2006GL027665.

,,,---- D. Koch, D. T. Shindell, and C. Gao, 2006b: Modeling the distribution of the volcanic aerosol cloud from the 1783-1784 Laki eruption. J. Geophys. Res., 111, D12209, https://doi .org/10.1029/2005JD006899.

Ortega-Gaucin, D., 2018: Measures to cope with drought in Mexico: A retrospective view (in Spanish). Rev. Col. San Luis, 15, 77-105, https://doi.org/10.21696 /rcsl8152018743.

Pausata, F. S. R., L. Chafik, R. Caballero, and D. S. Battisti, 2015: Impacts of high-latitude volcanic eruptions on ENSO and AMOC. Proc. Natl. Acad. Sci. USA, 112, 132784-132788, https://doi.org/10.1073 /pnas.1509153112.

Pfister, C., and Coauthors, 1999: Daily weather observations in sixteenth-century Europe. Climatic Change, 43, 111-150, https://doi.org/10.1023/A: 1005505113244.

Písek, J., and R. Brázdil, 2006: Responses of large volcanic eruptions in the instrumental and documentary climatic data over central Europe. Int. J. Climatol., 26, 439-459, https://doi.org/10.1002/joc.1249.

Prieto, M. R., D. Gallego, R. García-Herrera, and N. Calvo, 2005: Deriving wind force terms from nautical reports through content analysis. The Spanish and French cases. Climatic Change, 73, 37-75, https://doi .org/10.1007/s10584-005-6956-2.

Przybylak, R., A. Pospieszyńska, P. Wyszyński, and M. Nowakowski, 2014: Air temperature changes in Żagań (Poland) in the period from 1781 to 1792 . Int. J. Climatol., 34, 2408-2426, https://doi.org/10.1002 /joc.3847.

Raicich, F., 2008: Some features of Trieste climate from an eighteenth century diary (1732-1749). Climatic Change, 86, 211-226, https://doi.org/10.1007/s10584 $-007-9357-x$.

Sanderson, M. G., 2018: Daily weather in Dublin 1716-1734: The diary of Isaac Butler. Weather, 73, 179-182, https://doi.org/10.1002/wea.3029.

Schmidt, A., K. S. Carslaw, G. W. Mann, M. Wilson, T. J. Breider, S. J. Pickering, and T. Thordarson, 2010: The impact of the 1783-1784 AD Laki eruption on global aerosol formation processes and cloud condensation nuclei. Atmos. Chem. Phys., 10, 6025-6041, https:// doi.org/10.5194/acp-10-6025-2010.

, T. Thordarson, L. D. Oman, A. Robock, and S. Self, 2012: Climatic impact of the long-lasting 1783 Laki eruption: Inapplicability of mass-independent sulfur isotopic composition measurements. J. Geophys. Res., 117, D23116, https://doi.org/10.1029/2012JD018414.

Seager, R., L. Goddard, J. Nakamura, N. Henderson, and D. E. Lee, 2014: Dynamical causes of the 2010/11 Texas-northern Mexico drought. J. Hydrometeor., 15, 39-68, https:/doi.org/10.1175/JHM-D-13-024.1. Stahle, D. W., and Coauthors, 2016: The Mexican Drought Atlas: Tree-ring reconstructions of the soil moisture balance during the late pre-Hispanic, colonial, and modern eras. Quat. Sci. Rev., 149, 34-60, https://doi.org/10.1016/j.quascirev.2016.06.018.

Suárez Rivera, M., 2005: Felipe y Mariano de Zúñiga y Ontiveros: Impresores ilustrados y empresarios culturales (1761-1825). Universidad Nacional Autónoma de México Rep., 145 pp.

Swan, S. L., 1981: Mexico in the Little Ice Age. Interdiscip. Hist., 11, 633-648, https://doi.org/10.2307/203147.

Swingedouw, D., J. Mignot, P. Ortega, M. Khodri, M. Menegoz, C. Cassou, and V. Hanquiez, 2017: Impact of explosive volcanic eruptions on the main climate variability modes. Global Planet. Change, 150, 24-45, https://doi.org/10.1016/j.gloplacha.2017.01.006.

Therrell, M. D., 2005: Tree rings and "el Año del Hambre" in Mexico. Dendrochronologia, 22, 203207, https://doi.org/10.1016/j.dendro.2005.04.006.

—, D. W. Stahle, J. V. Diaz, E. H. C. Oviedo, and M. K. Cleaveland, 2006: Tree-ring reconstructed maize yield in central Mexico: 1474-2001. Climatic Change, 74, 493-504, https://doi.org/10.1007/s10584-006-6865-z. 
Thordarson, T., and S. Self, 2003: Atmospheric and environmental effects of the 1783-1784 Laki eruption: A review and reassessment. J. Geophys. Res., 108, 4011, https://doi.org/10.1029/2001JD002042.

— - , N. Óskarsson, and T. Hulsebosch, 1996: Sulfur, chlorine, and fluorine degassing and atmospheric loading by the 1783-1784 AD Laki (Skaftár fires) eruption in Iceland. Bull. Volcanol., 58, 205225, https://doi.org/10.1007/s004450050136.

Toohey, M., K. Krüger, H. Schmidt, C. Timmreck, M. Sigl, M. Stoffel, and R. Wilson, 2019: Disproportionately strong climate forcing from extratropical explosive volcanic eruptions. Nat. Geosci., 12, 100-107, https://doi.org/10.1038/s41561-018-0286-2.

Trigo, R. M., J. M. Vaquero, and R. B. Stothers, 2010: Witnessing the impact of the 1783-1784 Laki eruption in the Southern Hemisphere. Climatic Change, 99, 535-546, https://doi.org/10.1007/s10584-009-9676-1.

Van Den Besselaar, E. J. M., and Coauthors, 2015: International Climate Assessment \& Dataset: Climate services across borders. Bull. Amer. Meteor. Soc., 96, 16-21, https://doi.org/10.1175/BAMS-D-13-00249.1.

Vásquez-Bedoya, L. F., A. L. Cohen, D. W. Oppo, and P. Blanchon, 2012: Corals record persistent multidecadal SST variability in the Atlantic warm pool since 1775 AD. Paleoceanogr. Paleoclimatol., 27, PA3231, https://doi.org/10.1029/2012PA002313.

Villalba, R., M. Grosjean, and T. Kiefer, 2009: LongTerm Multi-Proxy Climate Reconstructions and
Dynamics in South America (LOTRED-SA): State of the art and perspectives. Palaeogeogr. Palaeoclimatol. Palaeoecol., 281, 175-179, https://doi.org/10.1016/j .palaeo.2009.08.007.

Wheeler, D., and R. García-Herrera, 2008: Ships' logbooks in climatological research: Reflections and prospects. Ann. N. Y. Acad. Sci., 1146, 1-15, https:// doi.org/10.1196/annals.1446.006.

Xoplaki, E., J. Luterbacher, H. Paeth, D. Dietrich, N. Steiner, M. Grosjean, and H. Wanner, 2005: European spring and autumn temperature variability and change of extremes over the last half millennium. Geophys. Res. Lett., 32, L15713, https://doi .org/10.1029/2005GL023424.

Yiou, P., M. Boichu, R. Vautard, M. Vrac, S. Jourdain, E. Garnier, F. Fluteau, and L. Menut, 2014: Ensemble meteorological reconstruction using circulation analogues of 1781-1785. Climate Past, 10, 797-809, https://doi.org/10.5194/cp-10-797-2014.

Zaiki, M., G. P. Können, T. Tsukahara, P. D. Jones, T. Mikami, and K. Matsumoto, 2006: Recovery of nineteenth-century Tokyo/Osaka meteorological data in Japan. Int. J. Climatol., 26, 399-423, https:// doi.org/10.1002/joc.1253.

Zúñiga-Vásquez, J. M., D. Cisneros-González, and M. Pompa-García, 2019: Drought regulates the burned forest areas in Mexico: The case of 2011, a record year. Geocarto Int., 34, 560-573, https://doi.org/10.1080/1 0106049.2017.1415986. 


\section{AMS Members}

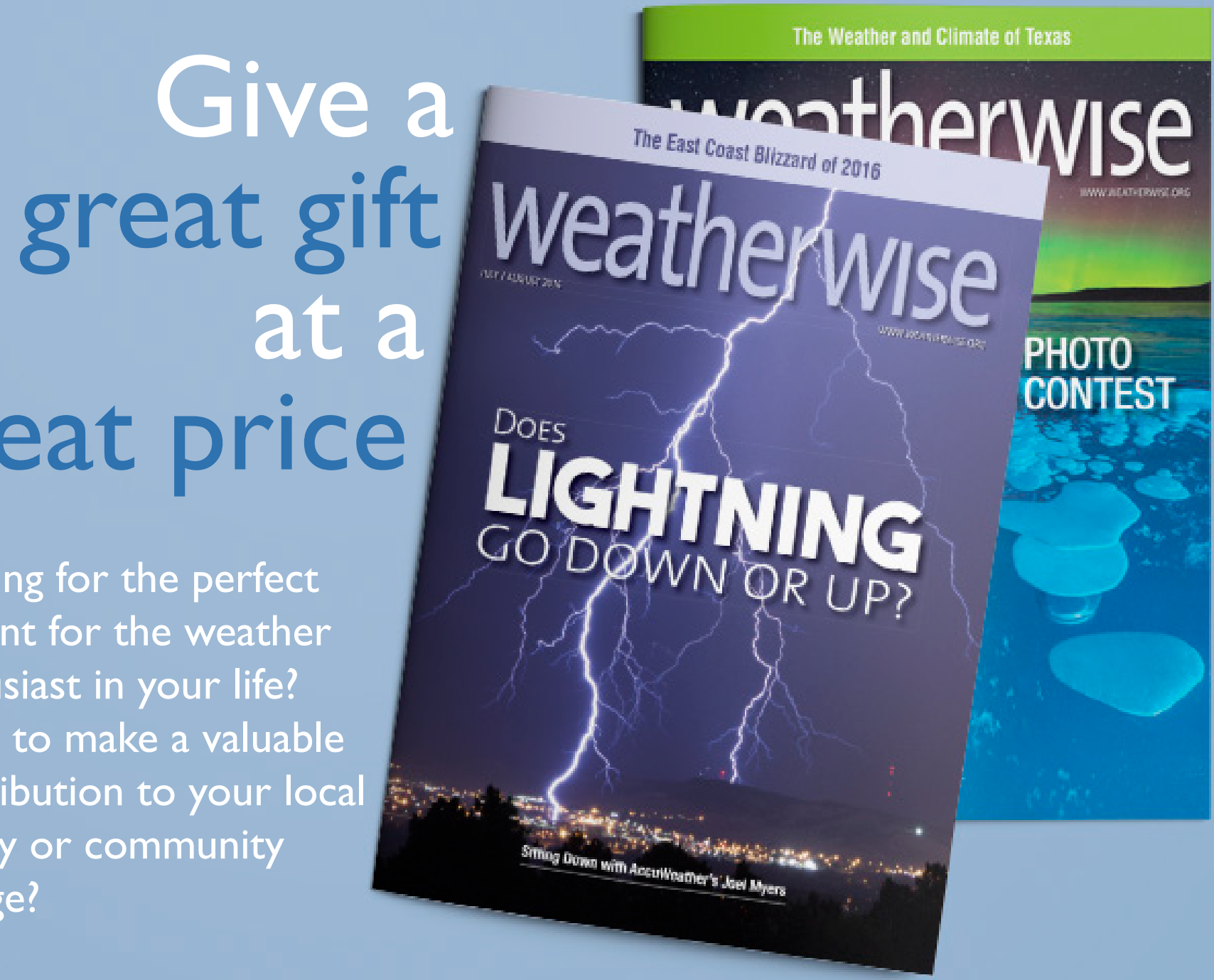

Send a subscription to Weatherwise magazine for just $\$ 24.95 *$-That's nearly $50 \%$ off the list price!

Contact Member Services by e-mail at amsmem@ametsoc.org or by phone at 617-227-2425 to place all of your Weatherwise orders today!
Written for a general audience, Weatherwise offers a colorful and nontechnical look at recent discoveries in meteorology and climatology.

Check out the latest table of contents at www.weatherwise.org.

\section{Want your own?}

Then order a personal subscription at the same great price. 